\title{
Additions to the smut fungi of the Iberian Peninsula
}

\author{
Teodor T. DENCHEV ${ }^{*}$, María P. MARTÍN², Martin KEMLER ${ }^{3}$, Cvetomir M. DENCHEV ${ }^{4}$ \\ 1,4Institute of Biodiversity and Ecosystem Research, Bulgarian Academy of Sciences, 2 Gagarin St., \\ 1113 Sofia, Bulgaria. \\ ${ }^{1,4}$ IUCN SSC Rusts and Smuts Specialist Group. \\ ${ }^{2}$ Real Jardín Botánico, RJB-CSIC, Plaza de Murillo 2, 28014 Madrid, Spain. \\ ${ }^{3}$ Evolution der Pflanzen und Pilze, Ruhr-Universität Bochum, ND 03, \\ Universitätsstr. 150, 44801 Bochum, Germany. \\ *Correspondence: ttdenchev@gmail.com

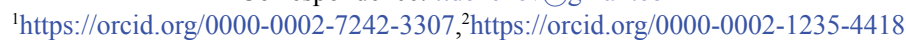 \\ ${ }^{3}$ https://orcid.org/0000-0002-0738-4233, ${ }^{4}$ https://orcid.org/0000-0001-6301-1629
}

\begin{abstract}
After examination of specimens, mainly from the herbarium (MA) and the mycological collection (MA-Fungi) of the Royal Botanic Garden of Madrid, we report several novelties on smut fungi within Europe. Two species of smut fungi, Sporisorium egyptiacum and Tilletia viennotii, are reported for the first time from Europe. A finding of Sphacelotheca polygoni-serrulati represents a second record for $\mathrm{Eu}-$ rope. Six species of smut fungi, Moreaua kochiana, Schizonella elynae, Sporisorium egyptiacum, Thecaphora thlaspeos, Tilletia viennotii, and Ustanciosporium majus, are recorded for the first time from the Iberian Peninsula. Five species of smut fungi, Moreaua kochiana, Schizonella elynae, Sporisorium egyptiacum, Thecaphora thlaspeos, and Ustanciosporium majus, are newly recorded from Spain. Three species, Moreaua kochiana, Sphacelotheca polygoni-serrulati, and Tilletia viennotii, are new for Portugal. A specimen of Moreaua kochiana represents a new record for France. Arabis serpillifolia is reported as a new host of Thecaphora thlaspeos. New distribution records from the Iberian Peninsula are given for Anthracoidea arenariae, Microbotryum minuartiae, M. silenes-saxifragae, and Tranzscheliella sparti. We also include a phylogenetic analysis of DNA sequences of Moreaua kochiana, generated in this study, to understand this species' relationships within its genus.
\end{abstract}

Keywords. Iberian Peninsula, Moreaua kochiana, smut fungi, Sporisorium egyptiacum, Tilletia viennotii.
Resumen. Tras examinar especímenes principalmente del herbario (MA) y de la colección de hongos (MA-Fungi) del Real Jardín Botánico de Madrid reportamos varias novedades de carboneros dentro de Europa. Dos especies de carbones, Sporisorium egyptiacum y Tilletia viennotii, se citan por primera vez para Europa. Reportamos también la segunda cita de Sphacelotheca polygoni-serrulati para Europa. Seis especies, Moreaua kochiana, Schizonella elynae, Sporisorium egyptiacum, Thecaphora thlaspeos, Tilletia viennotii, y Ustanciosporium majus, se citan por primera vez para la Península Ibérica; cinco especies, Moreaua kochiana, Schizonella elynae, Sporisorium egyptiacum, Thecaphora thlaspeos, y Ustanciosporium majus, son nuevas citas para España; tres especies, Moreaua kochiana, Sphacelotheca polygoni-serrulati, y Tilletia viennotii, son nuevas citas para Portugal. Una colección de Moreaua kochiana representa una nueva cita para Francia. Arabis serpillifolia se menciona por primera vez como un hospedante para Thecaphora thlaspeos. Se registran nuevas localidades en la Península Ibérica para Anthracoidea arenariae, Microbotryum minuartiae, M. silenes-saxifragae y Tranzscheliella sparti. Incluimos también un análisis filogenético de secuencias de ADN de dos especímenes de Moreaua kochiana, generadas en este estudio, para entender las relaciones filogenéticas de esta especie dentro su género.

Palabras clave. Península Ibérica, Moreaua kochiana, carbones, Sporisorium egyptiacum, Tilletia viennotii.

How to cite this article: Denchev T.T., Martín M.P., Kemler M., Denchev C.M. 2021. Additions to the smut fungi of the Iberian Peninsula. Anales del Jardín Botánico de Madrid 78: e109. https://doi.org/10.3989/ajbm.2589

Title in Spanish: Adiciones a los carbones de la Peninsula Ibérica.

Associate Editor: Ricarda Riina. Received: 4 February 2021; accepted: 5 May 2021; published online: 21 June 2021.

\section{INTRODUCTION}

The Iberian Peninsula harbours an unusually high diversity of vascular plants, ranking among the highest in Europe and the Mediterranean area with 6276 species (Aedo \& al. 2017). It is one of the most important centres of endemism with 1357 endemic species (22\% of the total number of species) (Buira \& al. 2020). This level of plant diversity is expected to correlate with a high species richness of plant parasitic fungi. Although the smut fungi of the
Iberian Peninsula are a subject of long-term studies (e.g., González Fragoso 1914, 1917, 1919, 1923, 1924a, b, 1926; Unamuno 1928, 1930a, b, c, 1931, 1934a, b, 1942; Ciferri 1933; Maire 1933, 1943; Losa España 1942, 1944, 1949, 1954; Alcalde 1944; Cámara \& Oliveira 1945; Cámara 1946; Guyot \& al. 1955, 1958, 1960, 1969; Jørstad 1962; Durrieu 1966; Losa Quintana 1970; Llorens i Villagrasa 1985; Denchev 1995, 1997; Almaraz \& Durrieu 1997; Al- 
maraz 1998, 1999a, b, c, 2002; Almaraz \& Medina 1998; Almaraz \& Telleria 1998; Vánky 2011; Kemler \& al. 2013, 2020; Denchev \& Denchev 2017; Kruse \& al. 2018), their inventory is incomplete and no regional monographic study has been published yet. Based on the modern taxonomic arrangement of the smut fungi, all known records from the Iberian Peninsula and Balearic Islands can be referred to 164 species.

In this article, we present new records of smut fungi from the Iberian Peninsula, as follows: two species for the first time from Europe, one species as a second record from Europe, six species for the first time from the Iberian Peninsula, five species as new for Spain, and three species as new for Portugal. We also generated DNA sequences (ITS and LSU rDNA regions) of Moreaua kochiana to provide a phylogenetic context for this species.

\section{MATERIAL AND METHODS}

The collections, on which the records are based, were obtained during a visit of two of the co-authors (T.T.D. \& C.M.D.) to the herbarium (MA) and mycological collection (MA-Fungi) at the Royal Botanic Garden, Madrid in April 2017. Dried specimens from the herbarium and mycological collection of the Royal Botanic Garden, Madrid and herbarium of the Botanic Garden and Botanical Museum Berlin were examined with a light microscope (LM) and scanning electron microscope (SEM). For LM observations and measurements, spores, spore balls, and sterile cells were mounted in lactoglycerol solution (w : la $: \mathrm{gl}=1: 1: 2$ ) on glass slides, gently heated to boiling point for rehydration, and then cooled. The measurements of spores and sterile cells are given in the form: min-max (extreme values) (mean \pm 1 standard deviation). For SEM, spores were attached to specimen holders by double-sided adhesive tape and coated with gold in an ion sputter. The surface structure of spores was observed and photographed at $10 \mathrm{kV}$ accelerating voltage using a Hitachi S-3000N scanning electron microscope. The shapes of spores, spore balls, and sterile cells are arranged in descending order of frequency. The width and height of the appendages of Ustanciosporium majus were measured in accordance with Denchev \& Denchev (2016). The descriptions given below are based entirely on the specimens examined.

To elucidate the relationship of one of the species, Moreaua kochiana with other species of the genus and the Anthracoideaceae, the ITS and LSU rDNA regions of two specimens were analysed. Genomic DNA isolation was performed using DNeasyPlant Mini Qiagen (Qiagen, Valencia, California, US), following the manufacturer's instructions, except in three steps: the incubation with the RNase was done overnight at $65^{\circ} \mathrm{C}$, a second drying at $20000 \times \mathrm{g}$ was done for 2 min after cleaning with AW buffer, and elution buffer was preheated to $60^{\circ} \mathrm{C}$. Polymerase chain reactions (PCR) were performed using Ready-To-Go PCR beads (GE Healthcare, Buckinghamshire, UK) to amplify DNA from two regions with the following primer combinations: ITS1F (Gardens \& Bruns 1993)/ITS4 (White \& al. 1990), to obtain DNA amplifications of the nuclear ribosomal internal transcribed spacer regions ITS1 and ITS2, including 5.8S, ITS nrDNA barcode (Schoch \& al. 2012); and LR0R/LR5r (White \& al. 1990), for nrLSU region. Amplicons obtained were purified using the kit QIAquick Gel Extraction (Qiagen) following the protocol defined by the manufacturer. The purified PCR products were sent to Macrogen (Madrid) for sequencing both directions using the same primers used in the amplifications. The consensus sequences were obtained with the software Sequencher (Gene Codes Corporation Inc, Ann. Arbor, Michigan, USA).

Alignment of the newly generated DNA sequences and of selected ones from NCBI was performed using MAFFT v7.450 under the -einsi option (Katoh \& al. 2002; Katoh \& Standley 2013). Ambiguous sites, leading and trailing gaps were removed using GBlocks (Castresana 2000) as implemented in Seaview (Gouy \& al. 2010), whereby smaller final blocks, gap positions within the final block, as well as less strict flanking positions were allowed. Alignment and GBlocks treatment were performed separately for the ITS and LSU datasets. Subsequently the two aligned matrices were concatenated using SequenceMatrix (Vaidya $\&$ al. 2011). Phylogenetic analyses were conducted using RAxML 7.3.5 (Stamatakis 2006) under the GTRGAMMA nucleotide substitution model and 1000 rapid bootstrap repetitions. The final ML tree was visualized using FigTree v1.4.3 (Rambaut 2016).

For the geographic distribution data provided to each taxon we follow the World Geographical Scheme for Recording Plant Distributions (Brummitt 2001).

\section{RESULTS AND DISCUSSION}

\section{Taxonomic treatment}

Anthracoidea arenariae (Syd.) Nannf., Bot. Not. 130: 365 (Nannfeldt 1977); Cintractia arenariae Syd., Ann. Mycol. 22: 289 (Sydow 1924). Type: on Carex arenaria, Poland, near Darłówko (as 'Pommern, Rügenwaldermünde'), Jul. 1893, P. Sydow s.n. (lectotype designated by Nannfeldt (1977: 365): S; isolectotypes: in Sydow, Ustilag., no. 5, as 'Ustilago caricis').

Specimen examined.-On Carex arenaria L.: PORTUGAL. Braga: Esposende, Apúlia, 4128'33.9"N, $8^{\circ} 46^{\prime 2} 23.7^{\prime \prime} \mathrm{W}, 9$ m, 6 Jun. 2010, A. Quintanar \& al. AQ3864, "Iter Lusitanicus, VI-2010” (MA 824694).

Distribution. - On Cyperaceae: Carex accrescens Ohwi (C. pallida C.A.Mey), C. arenaria, C. brizoides L., C. col- 
chica J.Gay (C. ligerica J.Gay), and C. praecox Schreb.; Europe, Asia, and North America (Vánky 2011).

Comments. - We report a new distribution record from Portugal.

Microbotryum minuartiae M.Lutz, Piątek, Kemler \& Chleb., Mycol. Res. 112: 1287 (Lutz \& al. 2008). Type: on Minuartia recurva (All.) Schinz \& Thell., Romania, Carpathian Mts, Bucegi Mts., Caraiman Peak, 2384 m, 26 Jul. 2004, A. Ronikier \& M. Ronikier s.n. (holotype: KRAM-F 55483).

Specimen examined. - On Minuartia villarii (Balb.) Wilczek \& Chenevard: SPAIN. León: Peña Ubiña, 1200 m, 10 Jul. 1994, S. Castroviejo s.n. (MA 247597).

Distribution. - On Caryophyllaceae: Minuartia spp.; Europe, Asia (Vánky 2011).

Comments. - In Spain, this species was known only from two localities: on Minuartia villarii from Province of Palencia, Velilla de Río Carrión, Espigüete; and on M. recurva subsp. condensata (C.Presl) Greuter \& Burdet from Province of Soria, Castillo Vinuesa, Santa Inés (Almaraz 2002: 41, as 'Microbotryum stellariae'). Molecular data are needed for clarification of the taxonomic status of the Microbotryum species on Minuartia villarii.

Microbotryum silenes-saxifragae M.Lutz, Piątek \& Kemler, IMA Fungus 4: 34 (Piątek \& al. 2013). Type: on Silene saxifraga, Austria, Carinthia, Villach, Finkenstein, southern part of the Kanzianiberg, near the church, 630 m, 24 Jun. 2006, M. Lutz s.n. (holotype: KR-M-23890).

Specimen examined.-On Silene saxifraga L.: SPAIN. Huesca: Sobrarbe, Chisagüés, 1650 m, 20 Jun. 1996, M. Carrasco, C. Martín Blanco, and M. Velayos 8426 (MA 609550).

Distribution. - On Caryophyllaceae: Silene saxifraga; Europe (Piątek \& al. 2013).

Comments. - A new distribution record from Spain.

Moreaua kochiana (Gäum.) Vánky, Mycotaxon 74: 352 (Vánky 2000); Tolyposporium kochianum Gäum., Ber. Schweiz. Bot. Ges. 41: 179 (Gäumann 1932); Thecaphora kochiana (Gäum.) Thirum. \& Neerg., Friesia 11: 186 (Thirumalachar \& Neergaard 1978). Type: on Schoenus $\times$ scheuchzeri (as 'S. ferrugineus $\times$ S. nigricans'), Switzerland, Kanton Zürich, at Greifensee Lake, Jun. 1932, W.Koch \& L.Zobrist s.n. (holotype: ZT). Fig. 2a-d.

Infection systemic. Sori around filaments and gynoecium of all flowers of infected plant, concealed by adjacent glumes and outwardly inconspicuous; the mass of spore balls blackish brown, initially agglutinated, later powdery. Spore balls irregular, subglobose, broadly ellipsoidal or ovoid, composed of (2-)5-50 or more, firmly united spores, occasionally single spores present, $(17.5-) 21-75(-85) \times$ (14.5-) 18-55(-68) $\mu \mathrm{m}$, dark reddish brown to very dark reddish brown or medium reddish brown when composed of few spores, opaque when composed of tens of spores. Spores in surface view irregularly rounded, irregularly polygonal, subcuneate, subglobose, elliptical or broadly elliptical, measured from the free side (5.5-)6.5-15(-16) $\times(5-) 6-11(-12) \mu \mathrm{m}$; radially (5-)6-15.5(-17) $\mu \mathrm{m}$ long; wall $1.2-3.2 \mu \mathrm{m}$ thick at free surface, $0.5-1.0 \mu \mathrm{m}$ thick at contact surfaces. In SEM, spore wall rugose to irregularly verrucose.

Specimens examined. - On Schoenus nigricans L.: PORTUGAL. Aveiro (as 'Beira Litoral'): Barrinha de Esmoriz, 12 Jul. 1977, Malato-Beliz 13586 and J.A. Guerra (MA 274860). SPAIN. Pontevedra: Cabo de Home, Playa de Melide, 9 Aug. 1985, E. Lago 566EL, S. Castroviejo, and X.R. Garcia (MA 875148). Valencia: Teresa de Cofrentes, Las Quebradas, 600 m, 3 Nov. 2003, M. Martínez Azorín s.n. (MA 836657).

Additional collections examined.-On Schoenus nigricans: AUSTRIA. Lower Austria: Gelber Berg near Purkersdorf, $0.9 \mathrm{~km}$ SE of Rudolfshöhe, 48 11'35"N, 16²'01"E, 315 m, 29 Jul. 1999, B. Wallnöfer 13708 (MA 691763). FRANCE. Occitanie: Montpellier, Valmaillargues, 27 May 1934, L. Zobrist 14447 (MA 361735).

Distribution. - On Cyperaceae: Schoenus carsei Cheeseman, $S$. nigricans, and Schoenus $\times$ scheuchzeri Brügger $(S$. ferrugineus L. $\times S$. nigricans L., Schoenus $\times$ intermedius Brügger); Europe (Austria, France, Germany, Italy, Netherlands, Portugal, Spain, Switzerland) and New Zealand.

Comments. - Moreaua kochiana is an infrequently collected smut fungus, considered by Vánky (1994: 273), in his monograph of the European smut fungi, as a rare species. Eighty-eight years after its description, it was known in Europe from only a few localities: on Schoenus nigricans, from the Netherlands (Ernst 2013) and Italy (Vánky, Ustilaginales Exsiccata, no. 861), and on Schoenus $\times$ scheuchzeri, from Switzerland (Gäumann 1932; Vánky 2000; Vánky, Ustilaginales Exsiccata, no. 189) and Germany (Kruse \& al. 2014). Recently, it was recorded from Austria, on both host plants (Denchev \& al. 2020b). Moreaua kochiana is reported herein for the first time from France, Spain, and Portugal, thus extending its geographic range to the Mediterranean region of France and the Iberian Peninsula. The significant increase in the knowledge about the distribution of this smut fungus suggests that its 'rarity' is rather due to its cryptic nature and that probably, this species has a larger geographic range.

Moreaua kochiana is also recorded on Schoenus carsei from New Zealand (McKenzie \& Vánky 2001) but this association needs re-examination with molecular methods considering that the range of $S$. carsei is confined to SE 
Table 1. List of sequences downloaded from GenBank and newly sequenced specimens used in the phylogenetic analyses with their respective GenBank accessions numbers for ITS and LSU.

\begin{tabular}{|c|c|c|c|c|}
\hline Species & Host & Voucher & ITS & LSU \\
\hline Anthracoidea aspera (Liro) Kukkonen & Carex chordorrhiza L.f. & 65/HМH 2774 & AJ586572 & AY563607 \\
\hline Anthracoidea sempervirentis Vánky & Carex sempervirens Vill. & $\begin{array}{l}\text { GLM-F105803/ } \\
\text { HMH } 3950\end{array}$ & KY424498 & AY563586 \\
\hline Cintractia amazonica Syd. \& P.Syd. & $\begin{array}{l}\text { Rhynchospora barbata (Vahl) } \\
\text { Kunth }\end{array}$ & MP 2008 & DQ875342 & AJ236142 \\
\hline Cintractia limitata G.P.Clinton & Cyperus sp. & AFTOL-ID 446 & DQ645508 & DQ645506 \\
\hline Dermatosorus cyperi Vánky & $\begin{array}{l}\text { Cyperus cellulosoreticulatus } \\
\text { Boeckeler }\end{array}$ & H.U.V. 15991 & DQ875343 & AJ236157 \\
\hline $\begin{array}{l}\text { Farysia itapuensis Landell \& P.Valente ex Denchev } \\
\& \text { T.Denchev }\end{array}$ & $\mathrm{n} / \mathrm{a}$ & CBS 10429 & KY103405 & KY107692 \\
\hline Farysia thuemenii (A.A.Fisch.Waldh.) Nannf. & $\mathrm{n} / \mathrm{a}$ & CBS 112.23 & MH854741 & MH866248 \\
\hline $\begin{array}{l}\text { Leucocintractia leucodermoides } \\
\text { M.Piepenbr. \& Begerow }\end{array}$ & $\begin{array}{l}\text { Rhynchospora holoschoenoides } \\
\text { (Rich.) Herter }\end{array}$ & HAJB 10431 & DQ875346 & DQ875363 \\
\hline Leucocintractia scleriae (DC.) M.Piepenbr. et al. & Rhynchospora triflora Vahl & MP 2074 & AY740025 & AJ236154 \\
\hline Moreaua bulbostylidis M.Piepenbr. & Bulbostylis capillaris C.B.Clarke & M 56581 & DQ875349 & DQ875366 \\
\hline Moreaua fimbristylidis Vánky \& R.G.Shivas & Fimbristylis dichotoma (L.) Vahl & M 56582 & DQ875350 & DQ875367 \\
\hline Moreaua kochiana (Gäum.) Vánky & Schoenus nigricans L. & MA 836657 & MW258623 & MW258619 \\
\hline Moreaua kochiana & Schoenus nigricans & MA 691763 & MW258622 & MW258618 \\
\hline Moreaua mauritiana (Syd.) Vánky & Fimbristylis ovata (Burm.f.) J.Kern & М 0040282 & KY424491 & - \\
\hline Orphanomyces arcticus (Rostr.) Savile & Carex davalliana $\mathrm{Sm}$. & GLM-F105778 & KY424454 & - \\
\hline $\begin{array}{l}\text { Portalia uljanishcheviana (Schwarzman) } \\
\text { V.González et al. }\end{array}$ & $\begin{array}{l}\text { Scirpoides holoschoenus (L.) } \\
\text { Soják (as 'Holoschoenus vulgaris') }\end{array}$ & $\begin{array}{l}12 \text { Jul. } 1949 \text {, } \\
\text { Schwarzman }\end{array}$ & - & EF118824 \\
\hline $\begin{array}{l}\text { Schizonella caricis-atratae Prillinger } \\
\text { et al. ex Denchev \& T.Denchev }\end{array}$ & Carex atrata $\mathrm{L}$. & CBS 123477 & NR_158881 & NG_064878 \\
\hline Schizonella melanogramma (DC.) J.Schröt. & Carex sp. & AFTOL-ID 1722 & DQ832212 & DQ832210 \\
\hline Stegocintractia luzulae (Sacc.) M.Piepenbr. et al. & Luzula pilosa (L.) Willd. & MP 2340 & DQ875353 & AJ 236148 \\
\hline Testicularia cyperi Klotzsch & Rhynchospora sp. & MCA3645 & KU147240 & KU147242 \\
\hline Tolyposporium junci (J.Schröt.) Woronin & Juncus bufonius L. & H.U.V. 17169 & AY344994 & AF009876 \\
\hline Tolyposporium neillii (G.Cunn.) Vánky \& McKenzie & Isolepis nodosa (Rottb.) R.Br. & H.U.V. 18533 & EU246951 & EU246952 \\
\hline Trichocintractia utriculicola (Henn.) M.Piepenbr. & $\begin{array}{l}\text { Rhynchospora corymbosa (L.) } \\
\text { Britton }\end{array}$ & H.U.V. 19316 & KY424453 & AF009877 \\
\hline Ustanciosporium gigantosporum (Liro) M.Piepenbr. & Rhynchospora alba (L.) Vahl & HRK023 & JN367300 & JN367325 \\
\hline Ustanciosporium standleyanum (Zundel) M.Piepenbr. & $\mathrm{n} / \mathrm{a}$ & AFTOL-ID 1915 & DQ846890 & DQ846888 \\
\hline
\end{tabular}




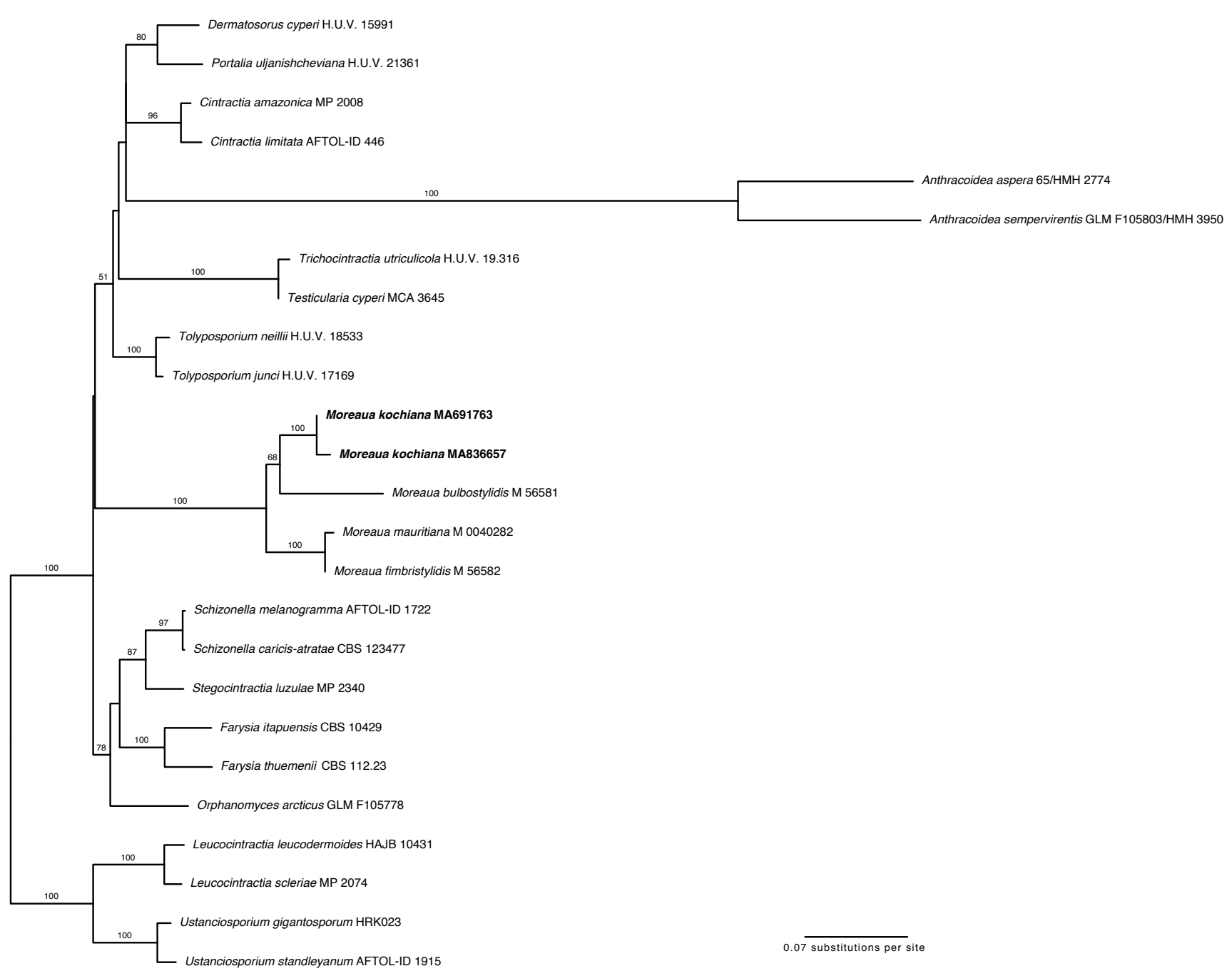

Fig. 1. Best-scoring ML phylogeny with bootstrap values $>50 \%$ written above branches. Specimens of Moreaua kochiana are shown in bold. The phylogeny was rooted with Leucocintractia leucodermis, L. scleriae, Ustanciosporium gigantosporum, and U. standleyanum.

Australia and New Zealand (Govaerts 2020) and that the smut fungi usually have narrow host specialisation.

The new sequences of Moreaua kochiana generated in this study represent the first molecular data for this species (Table 1). The ITS sequences are identical, whereas the LSU sequences show minor sequence differences. The two accessions of $M$. kochiana included in the phylogenetic analysis form a statistically well-supported clade (Fig. 1). The species is closely related to M. bulbostylidis M. Piepenbr. and all species of Moreaua form a highly supported clade (Fig. 1).

Schizonella elynae (A.Blytt) Liro, Ann. Acad. Sci. Fenn., Ser. A 42(1): 308 (Liro 1936); Schizonella melanogramma var. elynae A.Blytt, Forh. Vidensk.-Selsk. Christiania 1896 (6): 33 (Blytt 1896, as ' $\beta$ elynae'). Type: on Carex myo- suroides (as 'Elyna spicata'), Norway, Oppland, Dovre, Hjerkinn, 8 Aug. 1889, A. Blytt s.n. (lectotype designated by Lindeberg (1959: 57): O). Fig. 2e-h.

Infection systemic. Sori in leaves as striae or irregular spots, initially covered by the silvery epidermis which later ruptures disclosing a semi-agglutinated, blackish brown mass of spores. Spores joined in pairs, sometimes in threes, often separating into single spores, depressed on the contact side, in plane view suborbicular, irregular, broadly elliptical or ovate in outline, in plane view $(5-) 5.5-9(-9.5) \times(4.5-) 5-$ $7.5(-8.5)(7.1 \pm 0.9 \times 6.1 \pm 0.6) \mu \mathrm{m}(\mathrm{n}=100)$, in side view usually irregularly hemispherical; light yellowish brown to medium reddish brown; wall unevenly thickened, 0.61.3(-1.6) $\mu \mathrm{m}$ thick, thinner and lighter on the contact side, smooth. In SEM, spore wall densely, minutely verruculose, 


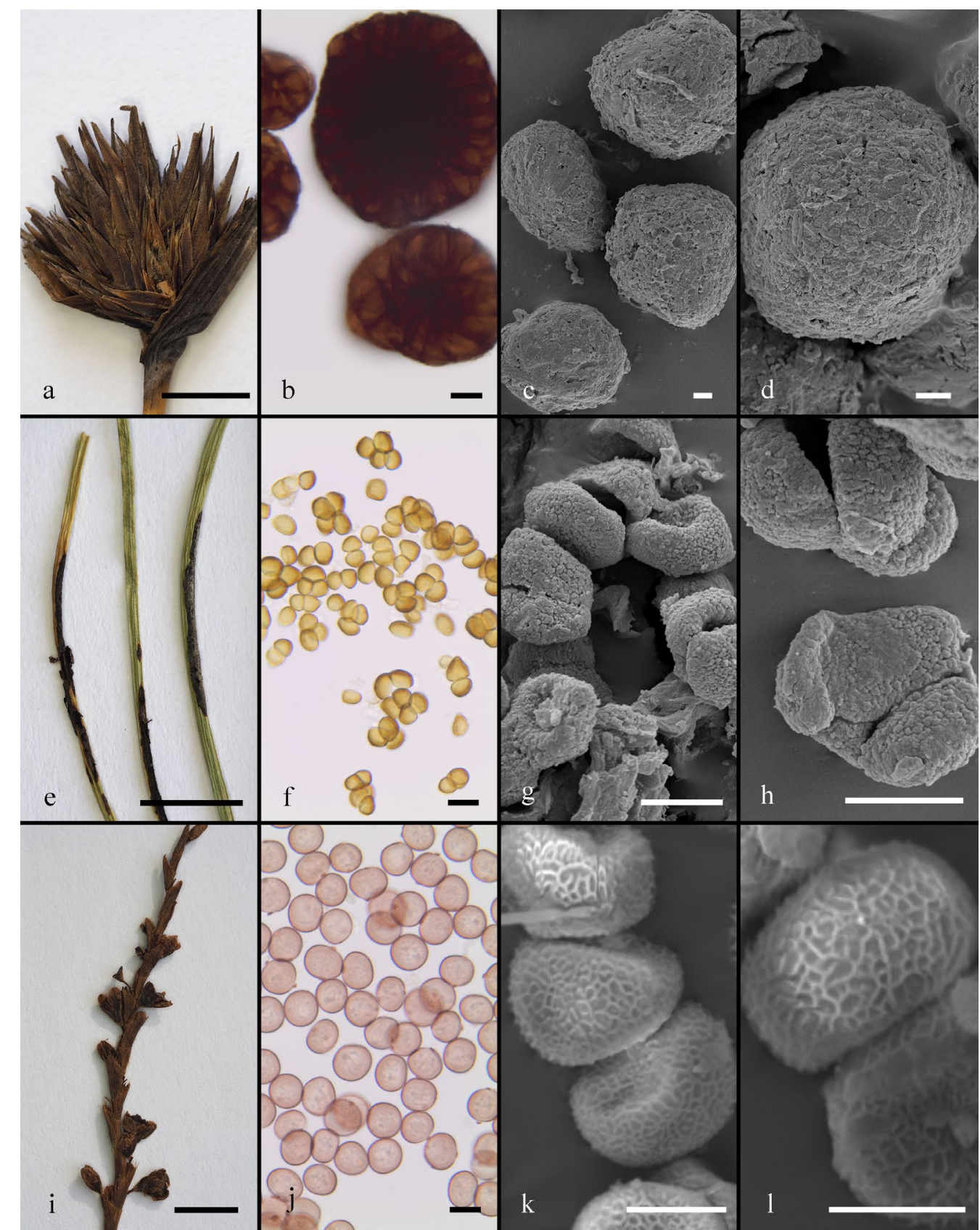

Fig. 2. Moreaua kochiana (Gäum.) Vánky (MA 836657): a, habit; b, spore balls in LM; c, d, spore balls in SEM. Schizonella elynae (A.Blytt) Liro (MA 342212): e, habit; f, spores in LM; g, h, spores in SEM. Sphacelotheca polygoni-serrulati Maire (B 10 0506861): i, habit; j, spores in LM; k, l, spores in SEM. Scale bars: a, e, i $=0.5 \mathrm{~cm}, \mathrm{~b}, \mathrm{f}, \mathrm{j}=10 \mu \mathrm{m}, \mathrm{c}, \mathrm{d}, \mathrm{g}, \mathrm{h}, \mathrm{k}, \mathrm{l}=5 \mu \mathrm{m}$.

warts often confluent, forming small groups; ornaments up to $0.15 \mu \mathrm{m}$ in height; contact side with a concave area.

Specimen examined. - On Carex myosuroides Vill. (Kobresia myosuroides (Vill.) Fiori): SPAIN. Cantabria: Picos de Europa, Fuente Dé, upper station of the cable car to Horcados Rojos, 1900-2400 m, 14 Jul. 1985, M. Luceño and P. Vargas 419 (MA 342212).
Distribution. - On Cyperaceae: Carex myosuroides; Europe, Asia (East Siberia), and North America (Canada, Greenland).

Comments. - Both the smut fungus and its host plant are circumpolar-alpine species (Denchev \& al. 2020a; Elven $\&$ al. 2020). In Europe, Schizonella elynae is known from North Europe (Iceland, Norway, and Sweden) and the Alps 
(Germany, Austria, and Italy) (Blytt 1896; Lindeberg 1959; Jørstad 1963; Helgi Hallgrímsson \& Guðríður Gyða Eyjólfsdóttir 2004; Kruse \& al. 2019; Denchev \& al. 2020a). The present record extends the geographic range of this species to the Iberian Peninsula. Schizonella elynae, on Carex pilulifera L., was erroneously reported from Spain by Almaraz (1998: 123, 2002: 47), based on a wrongly revised specimen of González Fragoso, published by him (1924a: 121) as $S$. melanogramma (DC.) J.Schröt. on C. praecox Schreb.

Sphacelotheca polygoni-serrulati Maire, Bull. Soc. Hist. Nat. Afrique N. 8: 74 (Maire 1917). Type: on Persicaria decipiens (as 'Polygonum serrulatum'), Algeria, Algiers, Réghaïa, 15 Oct. 1915, R. Maire s.n. (lectotype designated by Vanky \& Oberwinkler (1994: 28): MPU; isolectotypes: in Maire, Mycotheca Boreali-Africana, no. 229). Fig. 2i-1.

Sori in some ovaries of an inflorescence, ovoid, 2.5-4 $\mathrm{mm}$ long, covered by a thick, brownish and brittle peridium which later ruptures irregularly from its apex, exposing a semi-agglutinated, powdery on the surface, date brown (based on Colour identification chart of Anonymous 1969) mass of spores, surrounding a single columella. Spores subglobose, broadly ellipsoidal, slightly irregular, ovoid or globose, often slightly flattened, initially in chains, connected by disjunctors, later single, usually with two or sometimes three persistent appendages on the opposite sides of the spores (remnants of disjunctors), (9.5-)10 $13(-14) \times(8.5-) 9.5-12(-13)(11.6 \pm 0.8 \times 10.4 \pm 0.7) \mu \mathrm{m}$ $(\mathrm{n}=100)$, medium vinaceous; wall finely and irregularly reticulate, evenly thickened, $0.6-1.0 \mu \mathrm{m}$ thick, spore profile not affected. In SEM, spore wall incompletely reticulate or labyrinthiform.

Specimen examined.-On Persicaria decipiens (R.Br.) K.L.Wilson (as 'Polygonum salicifolium Brouss. ex Willd.'): PORTUGAL. Setúbal: Santiago do Cacem, Ribeira da Lezíria, 24 Oct. 1979, L.A. Grandvaux Barbosa 13330 (B 10 0506861).

Distribution. -On Polygonaceae: Persicaria barbata (L.) H.Hara (Polygonum barbatum L.), P. decipiens (Polygonum salicifolium Brouss. ex Willd., P. serrulatum Lag.), P. maculosa S.F.Gray, P. pulchra (Blume) Soják, and $P$. setosula (A.Rich.) K.L.Wilson (Polygonum setosulum A.Rich.); Europe (Portugal, Spain), Africa, Australasia (Australia, New Zealand).

Comments. - Sphacelotheca polygoni-serrulati is recorded here for the first time from Portugal. In Europe, this smut fungus has been previously reported only once, for Spain: on Persicaria decipiens (as 'Polygonum salicifolium') in the Province of Barcelona, Gavá (Almaraz 2002). The present finding represents the second record for Europe.

In Africa, it is known from single localities in Algeria, Cameroon, the D.R. of the Congo, Madeira, Uganda,
Rwanda, and Zambia (Maire 1917; Liro 1924; Zundel 1944; Deml \& al. 1985; Vánky \& al. 2011; Piątek \& al. 2012).

Sporisorium egyptiacum (A.A.Fisch.Waldh.) Vánky (as 'aegypticum'), Mycotaxon 33: 371 (Vánky 1988); Ustilago egyptiaca A.A.Fisch.Waldh. (as 'aegyptiaca'), Hedwigia 18: 100 (Fischer von Waldheim 1879). Type: on Schismus barbatus (as 'S. calycinus'), Egypt, near Cairo, 1820-1824, G. Ehrenberg s.n. (holotype: LE). Fig. 3a-d.

Infection systemic, in all spikelets of the inflorescence. Sori in the basal part of florets leaving intact the glumes and the distal part of the floret (in spikelets with mature sori, the basal part of the florets appears bullate, similar to sori of Ustilago bullata Berk.), 1.5-2.5 × 0.7-1.2 mm, ovoid or ellipsoidal, partially visible between the spreading glumes; initially covered by a thin, yellowish brown peridium that soon ruptures irregularly from its basal part, exposing a single, flattened, tapering columella as long as the sorus, surrounded by a powdery, blackish brown mass of spores and sterile cells. The infected plants are stunted. Sterile cells single, in irregular groups or in short chains, irregular, subglobose, broadly ellipsoidal or ellipsoidal, (67-11.5(-12.5) × (5.5-)6.5-10(-11) $(9.4 \pm 1.6 \times 8.0 \pm 1.1)$ $\mu \mathrm{m}(\mathrm{n}=50)$, hyaline; wall $0.6-1.0 \mu \mathrm{m}$ thick. Spores irregularly rounded, subglobose, broadly ellipsoidal, ellipsoidal or ovoid, (10.5-)11.5-14.5(-15.5) × (8.5-)9.5-12.5(-13.5) $(13.0 \pm 0.8 \times 11.1 \pm 0.9) \mu \mathrm{m}(\mathrm{n}=100)$, medium reddish brown; wall $0.7-1.3 \mu \mathrm{m}$ thick, minutely echinulate, ornaments up to $0.4(-0.5) \mu \mathrm{m}$ high, spore profile slightly affected. In SEM, spore surface densely punctate between the spines.

Specimen examined. - On Schismus barbatus (L.) Thell. (as 'S. calycinus Cosson \& Durieu'): SPAIN. Almería: Rioja near Gérgal, 11 Mar. 1970, J. Fernández Casas s.n. (MA 415522).

Distribution.-On Poaceae: Schismus arabicus Nees, S. barbatus (S. calycinus (Loefl.) K.Koch, S. minutus (Hoffm.) Roem. \& Schult.); Europe (Spain), North Africa (Egypt, Libya), Asia, Australia.

Comments. - This finding of Sporisorium egyptiacum represents the first record for the Iberian Peninsula and Europe (cfr. Vánky 1994, 2005).

Thecaphora thlaspeos (Beck) Vánky, Mycotaxon 89: 111 (Vánky 2004); Tilletia thlaspeos Beck, Verh. K. K. Zool.Bot. Ges. Wien 35: 362 (Beck 1886); Ustilago thlaspeos (Beck) Lagerh., in Sydow, Ustilaginales Exsiccata: no. 118 (1897). Type: on Thlaspi alpestre, Austria, Burgenland, near Redlschlag, V. Borbás s.n. (HUV 4776 in BRIP). Fig. 3e-h.

Infection systemic. Sori in siliquae, replacing the seeds. Spore mass powdery, yellowish brown, released when the siliquae open. Spores single, variable in shape, irregular, 


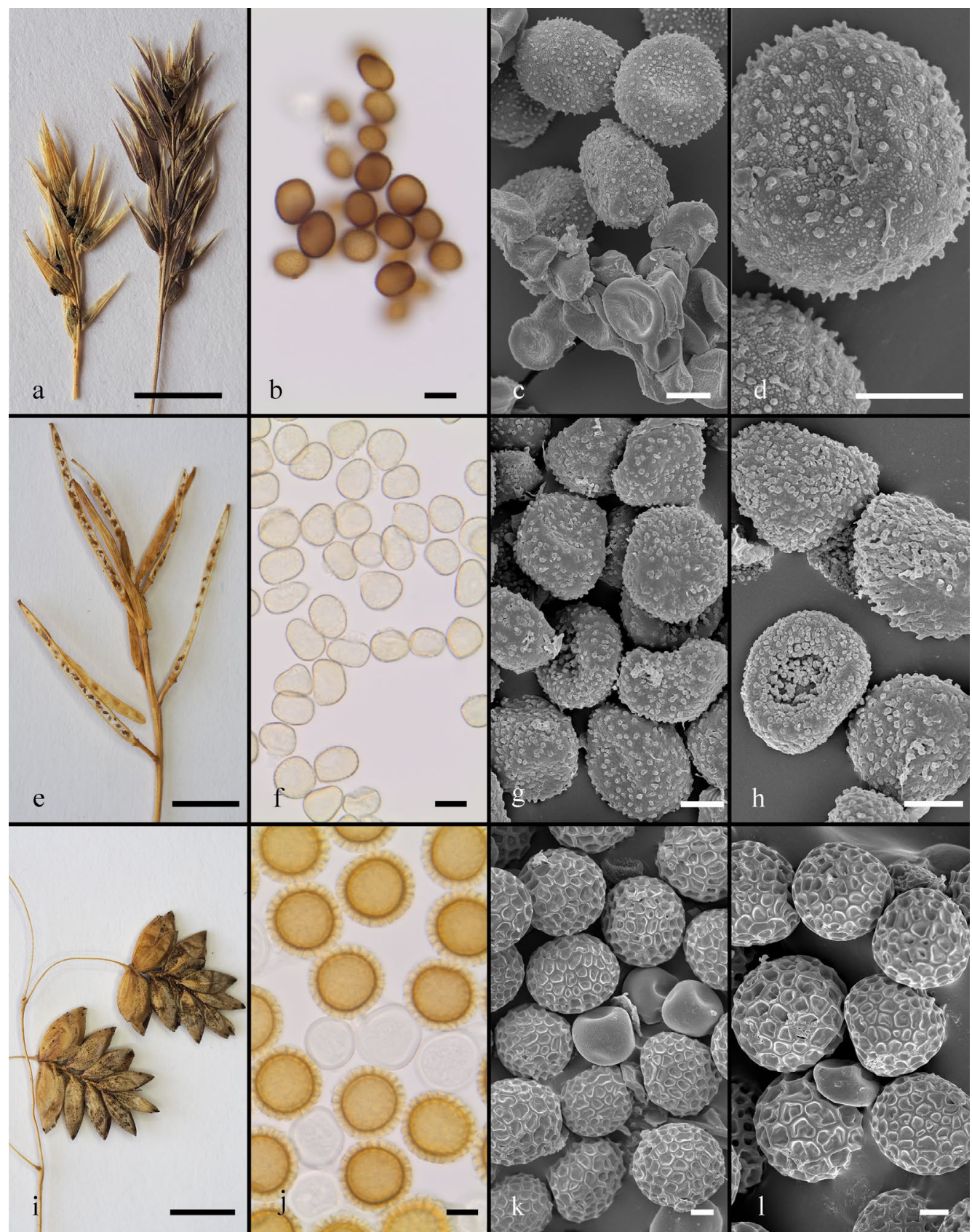

Fig. 3. Sporisorium egyptiacum (A.A.Fisch.Waldh.) Vánky (MA 415522): a, habit; b, spores in LM; $\mathbf{c}, \mathbf{d}$, spores and sterile cells in SEM. Thecaphora thlaspeos (Beck) Vánky (MA 331875): e, habit; f, spores in LM; g, h, spores in SEM. Tilletia viennotii Syd. (Álvarez \& al. 1344 IA, MA-Fungi s.n.): i, habit; j, spores and sterile cells in LM; k, l, spores and sterile cells in SEM. Scale bars: a, e, i $=0.5 \mathrm{~cm}, \mathrm{~b}, \mathrm{f}, \mathrm{j}=10 \mu \mathrm{m}, \mathrm{c}, \mathrm{d}, \mathrm{g}, \mathrm{h}, \mathrm{k}, \mathrm{l}=5 \mu \mathrm{m}$.

subglobose, broadly ellipsoidal, ellipsoidal, elongated, globose, ovoid or reniform, $(9.5-) 10.5-18(-20) \times(8-) 9-$ $12(-13.5)(13.4 \pm 1.8 \times 10.5 \pm 1.0) \mu \mathrm{m}(\mathrm{n}=100)$, light to medium yellowish brown; wall $0.5-1.1 \mu \mathrm{m}$ thick, verrucose-echinate, ornaments up to $0.6 \mu \mathrm{m}$ high, on a restricted area of the wall ornaments coarser and higher, up to 2.0(-2.4) $\mu \mathrm{m}$ high. In SEM, spore wall verrucose-echinate, smooth to sparsely punctate between the ornaments.
Specimen examined.-On Arabis serpillifolia Vill.: SPAIN. Huesca: Valle de Ordesa, Faja Pelay, 1400 m, 29 Aug. 1969, J. Fernández Casas s.n. (MA 331875).

Distribution. - On Brassicaceae: Alyssum reiseri Velen., Arabidopsis petraea (L.) V.I.Dorof. (Cardaminopsis petraea (L.) Hiitonen), Arabis alpina L., A. ciliata Clairv. (A. corymbiflora Vest), A. hirsuta (L.) Scop., A. pubescens (Desf.) Poir., A. sagittata (Bertol.) DC., A. serrata 


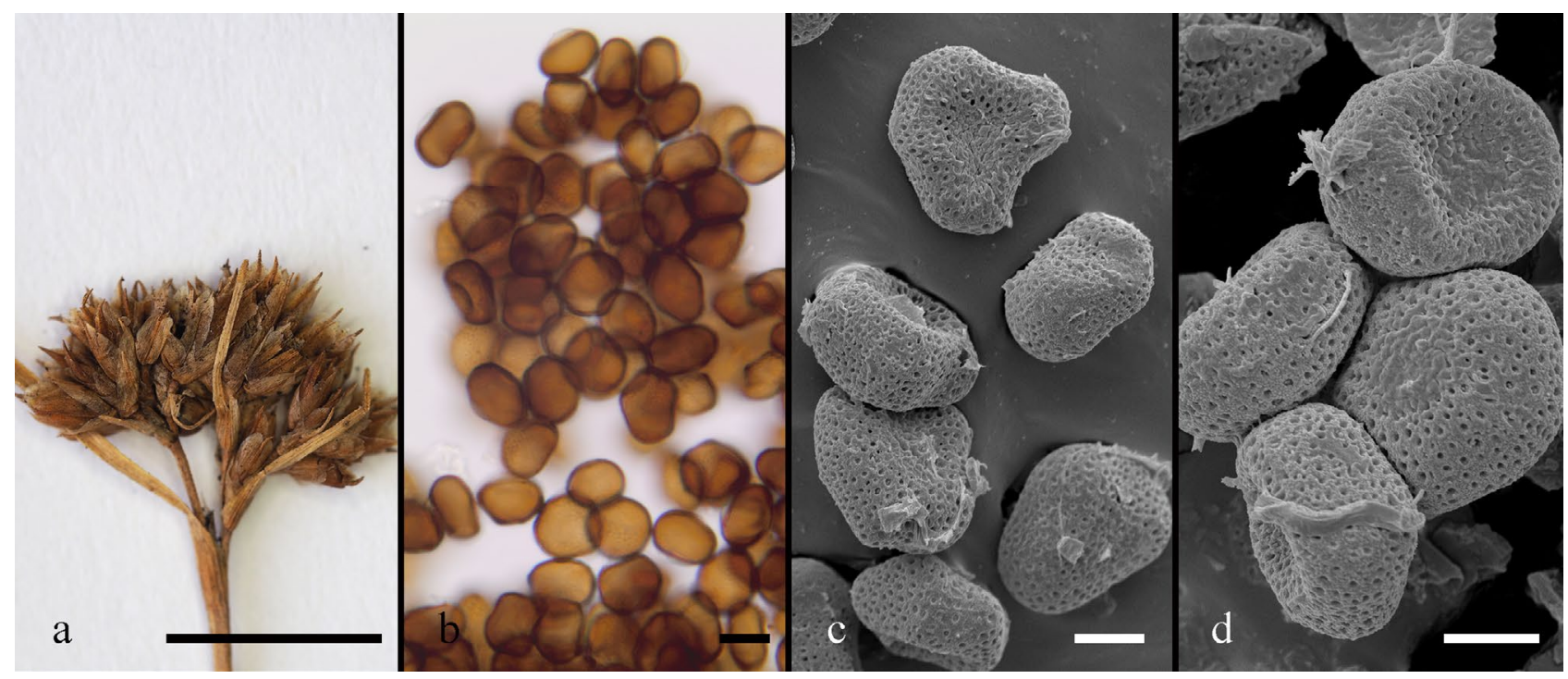

Fig. 4. Ustanciosporium majus (Desm.) M.Piepenbr.: a, habit (MA 798317); b, spores in LM (MA 483460); c, d, spores in SEM (MA 483460). Scale bars: $\mathrm{a}=0.5 \mathrm{~cm}, \mathrm{~b}=10 \mu \mathrm{m}, \mathrm{c}, \mathrm{d}=5 \mu \mathrm{m}$.

var. hallaisanensis (Nakai) Ohwi, Cardamine bellidifolia L., Draba aizoides L., D. alpina L., D. incana L., Erysimum diffusum Ehrh., E. welcevii Urum., Noccaea alpestris (Jacq.) Kerguélen (Thlaspi alpinum Crantz), Noccaea brachypetala (Jord.) F.K.Mey. (Thlaspi brachypetalum Jord.), and N. caerulescens (J.Presl \& C.Presl) F.K.Mey. (Thlaspi alpestre L.); Europe, North Africa (Algeria), and Asia (South Korea).

Comments. - Thecaphora thlaspeos is a rather inconspicuous species, without obvious infection symptoms. This smut fungus can be seen once siliquae are opened and the spore mass becomes exposed (Denchev \& Denchev 2019). Thecaphora thlaspeos is reported here for the first time from the Iberian Peninsula. Arabis serpillifolia is endemic to Europe, known from the Pyrenees, the Iberian System, Jura Mts, and the Alps (Jones \& Akeroyd 1993; Talavera 1993). It is a new host plant record for T. thlaspeos.

Tilletia viennotii Syd., Ann. Mycol. 35: 258 (Sydow 1937). Type: on Briza maxima, Madeira Island, Curral Grande, Aug. 1936, G. Viennot-Bourgin s.n. (holotype: PC). Fig. 3i-1.

Infection systemic. Sori in ovaries of all spikelets of an infected plant, hidden by the glumes, $2.5-3.5 \times 1.5-2$ $\mathrm{mm}$, covered by a thin, brown pericarp with parallel veins. Mass of spores and sterile cells powdery, umber (based on Rayner 1970) or snuff brown (based on Colour identification chart of Anonymous 1969), evident after rupturing of the pericarp. Sterile cells slightly irregular, subglobose or broadly ellipsoidal, (16.5-)17.5-23(-24) × 16-21($22.5)(20.4 \pm 1.5 \times 18.7 \pm 1.3) \mu \mathrm{m}(\mathrm{n}=50)$, hyaline; cell wall two-layered, (1.3-)1.5-2.3(-2.6) $\mu \mathrm{m}$ thick. In SEM, smooth to punctate. Spores subglobose, broadly ellipsoidal or globose, (22.5-)23.5-28(-29) $\times(21.5-) 22.5-26(-27)$ $(25.9 \pm 1.2 \times 24.2 \pm 1.0) \mu \mathrm{m}(\mathrm{n}=100)$, medium yellowish brown to medium reddish brown, reticulate; spore wall (4.0-)4.3-5.5(-5.8) $\mu \mathrm{m}$ thick (including reticulum); meshes 6-8(-9) per spore diameter, polyhedral or irregular, (0.8-)1.2-5.0(-6.5) $\mu \mathrm{m}$ long; muri $22-31$ on equatorial circumference, in optical median view subacute, acute or blunt, (2.3-)2.6-3.7(-4.2) $\mu \mathrm{m}$ high; often covered by thin, hyaline sheath. In SEM, interspaces smooth, sometimes with a very low, hemispherical protuberance.

Specimen examined. - On Briza maxima L.: PORTUGAL. Beira Alta: Guarda, between Vale de Estrela and Guarda, 950 m, 19 Jul. 1997, I. Álvarez 1344 IA, M.A. García, and L. Medina (MA-Fungi s.n.).

Distribution. - On Poaceae: Briza maxima, B. minor L.; Europe (Portugal), Africa, and Australia.

Comments. - Briza maxima and B. minor are native to the Mediterranean and Macaronesian regions (B. minor also in SW Asia to Iran) but they have been introduced to many countries throughout the world, as ornamental species, and widely naturalised there (Isabel \& al. 2018; Clayton \& al. 2020). Within its native range, B. maxima is reported as infected by Tilletia viennotii only from Madeira (Sydow 1937) while outside this range, there are records from South Africa (Zundel 1938; Vánky 1998; Vánky \& al. 2011) and Australia (Vánky \& Shivas 2008). Briza minor is known as a host plant only from Australia (Vánky \& Shivas 2008). Thus, the finding reported here is of high interest, as it represents the first record of this smut fungus not only from the Iberian Peninsula but also from Europe. 
Tranzscheliella sparti (Massenot) Vánky, Mycotaxon 85: 4 (Vánky 2003); Ustilago sparti Massenot, in Guyot \& al., Rev. Pathol. Vég. Entomol. Agric. France 34: 216 (Guyot $\&$ al. 1955). Type: on Lygeum spartum, Tunisia, near Hadjeb-el-Aioun, 1 Oct. 1953, L. Guyot s.n. (lectotype designated by Vánky (1994: 376): PC; syntype: near Kasserine, 2 Oct. 1953, L. Guyot s.n.).

Specimen examined. - On Lygeum spartum L.: SPAIN. Ciudad Real: Alcázar de San Juan, 640 m, 25 Aug. 1998, L. Medina s.n. (MA-Fungi s.n.).

Distribution. - On Poaceae: Lygeum spartum; South Europe and North Africa (Vánky 2011).

Comments. - A new distribution record from Spain.

Ustanciosporium majus (Desm.) M. Piepenbr., Nova Hedwigia 70: 341 (Piepenbring 2000), s. str.; Ustilago montagnei var. major Desm., in Desmazières, Pl. Cryptog. N. France, ed. 1: no. 2126 (Desmazières 1851); Cintractia major (Desm.) Liro, Ann. Acad. Sci. Fenn., Ser. A 42(1): 46 (Liro 1935, in Liro 1938); Ustilago intercedens Lehtola, Ann. Bot. Soc. Zool.-Bot. Fenn. "Vanamo" 17(3): 23 (Lehtola 1942). Type: on Rhynchospora alba, France, s.coll. (isotype: in Desmazières, Pl. Cryptog. N. France, ed. 1: no. 2126, as 'Ustilago montagnei var. major'). Fig. $4 \mathrm{a}-\mathrm{d}$.

Infection systemic. Sori in all spikelets of an infected inflorescence, hidden by the glumes, formed around more or less destroyed inner floral organs, naked; spore mass blackish brown, initially semi-agglutinated, later powdery. Spores single, flattened, in plane view usually irregularly rounded to subpolygonal or broadly elliptical, sometimes suborbicular or ovate, in plane view 11-16($17) \times(8.5-) 9.5-13(-14)(13.6 \pm 1.2 \times 11.6 \pm 1.0) \mu \mathrm{m}(\mathrm{n}$ $=100)$, in side view $6.5-9.5 \mu \mathrm{m}$ thick, medium reddish brown; wall evenly to unevenly thickened, $0.5-1.0(-1.2)$ $\mu \mathrm{m}$ thick, finely, densely foveolate, sometimes with a hyaline or subhyaline appendage on one or both of the flattened sides, appendages wider than high 4-6.5 $\mu \mathrm{m}$ wide, 2-3.5 $\mu \mathrm{m}$ high; detached appendages occasionally present. In SEM, spore wall densely foveolate, punctate between the foveoles.

Specimens examined.-On Rhynchospora alba (L.) Vahl: SPAIN, Ávila: Navalguijo, Aug. 1986, M. Luceño and P. Vargas s.n. (MA 483460). Zamora: Rosinos de la Requejada, Doney de la Requejada, bank of Rio Negro River, 1100 m, 10 Oct. 2002, P. Bariego PB-1941 (MA 798317).

Distribution. - On Cyperaceae: Rhynchospora alba; Europe, Asia, and North America.

Comments. - This smut fungus is recorded here for the first time from the Iberian Peninsula.

\section{ACKNOWLEDGEMENTS}

This research received support from the SYNTHESYS Project http:// www.synthesys.info/, financed by European Community Research Infrastructure Action under the FP7 "Capacities" Program at the Real Jardín Botánico (CSIC) (Grant no. ES-TAF-6618) and the Botanic Garden and Botanical Museum Berlin (Grant no. DE-TAF-4056). The assistance of Dr Margarita Dueñas (MA-Fungi) is kindly acknowledged.

\section{REFERENCES}

Aedo C., Buira A., Medina L. \& Fernández-Albert M. 2017. The Iberian vascular flora: richness, endemicity and distribution patterns. In Loidi J. (ed.), The vegetation of the Iberian Peninsula 1: 101-130. Springer, Berlin.

Alcalde M.B. 1944. Acerca de "Ustílago cardui sobre Cirsium". Anales del Jardin Botánico de Madrid 4: 141-143.

Almaraz T. \& Durrieu G. 1997. Ustilaginales from the Spanish Pyrenees and Andorra. Mycotaxon 65: 223-236.

Almaraz T. \& Medina L. 1998. Fragmenta chorologica occidentalia, Fungi, 6322. Anales del Jardin Botánico de Madrid 56: 124.

Almaraz T. \& Telleria M.T. 1998. On Ustilago sparti (Ustilaginales, Basidiomycotina). Mycotaxon 67: 495-504.

Almaraz T. 1998. Fragmenta chorologica occidentalia, Fungi, 6308-6321. Anales del Jardin Botánico de Madrid 56: 123-124.

Almaraz T. 1999a. Fragmenta chorologica occidentalia, Fungi, 69186935. Anales del Jardin Botánico de Madrid 57: 141-143.

Almaraz T. 1999b. Quelques Ustilaginales de 1'Andalousie (Espagne). Cryptogamie, Mycologie 20: 5-10.

Almaraz T. 1999c. Nuevas aportaciones corológicas de Ustilaginales. Boletín de la Sociedad Micológica de Madrid 24: 95-102.

Almaraz T. 2002. Bases corológicas de Flora Micológica Ibérica. Números 1766-1932. In Pando F. \& Hernández J.C. (eds.), Cuadernos de trabajo de Flora Micológica Ibérica vol. 17. Editorial CSIC, Real Jardín Botánico, Madrid.

Anonymous. 1969. Flora of British Fungi. Colour Identification Chart. Her Majesty's Stationery Office, Edinburgh.

Beck G. 1886. Zur Pilzflora Niederösterreichs. 3. Verhandlungen der Kaiserlich-Königlichen Zoologisch-Botanischen Gesellschaft in Wien 35: 361-376.

Blytt A. 1896. Bidrag til kundskaben om Norges soparter. IV. Peronosporaceæ, Chytridiaceæ, Protomycetaceæ, Ustilagineæ, Uredineæ. Forhandlinger $i$ Videnskabs-Selskabet i Kristiania 1896(6): 1-75.

Brummitt R.K. 2001. World Geographical Scheme for Recording Plant Distributions. Ed. 2. Plant Taxonomic Database Standards No. 2 International Working Group on Taxonomic Databases for Plant Sciences (TDWG). Hunt Institute for Botanical Documentation, Carnegie Mellon University, Pittsburgh. Website: http://grassworld.myspecies.info/sites/ grassworld.myspecies.info/files/tdwg_geo2.pdf [accessed 12 Nov. 2020].

Buira A., Cabezas F. \& Aedo C. 2020. Disentangling ecological traits related to plant endemism, rarity and conservation status in the Iberian Peninsula. Biodiversity and Conservation 29: 1937-1958.

Cámara M.S. \& Oliveira A.L.B. 1945. Contributio fungorum minima in Lusitania collectorum. Ustilaginales 1. Agronomia Lusitana 7: 101-108.

Cámara M.S. 1946. Contributiones ad mycofloram Lusitaniae. Centuria XII. Agronomia Lusitana 8: 19-71. 
Castresana J. 2000. Selection of conserved blocks from multiple alignments for their use in phylogenetic analysis. Molecular Biology and Evolution 17: 540-552.

Ciferri R. 1933. Ustilaqinales esotici nuovi o rari. 1. Nuovo Giornale Botanico Italiano 40: 252-268.

Clayton W.D., Govaerts R., Harman K.T., Williamson H. \& Vorontsova M. 2020. Briza. In Clayton W.D. \& al. (eds.), World checklist of Poaceae Royal Botanic Gardens, Kew. Website: http://wcsp.science.kew.org [accessed: 19 Nov. 2020].

Deml G., Oberwinkler F. \& Bauer R. 1985. Studies in Heterobasidiomycetes, Part 38. Sphacelotheca polygoni-persicariae G. Deml \& Oberw. spec. nov. Phytopathologische Zeitschrift 113: 231-242.

Denchev C.M. 1995. New host and distribution records of Microbotryum violaceo-verrucosum (Ustilaginales). Nova Hedwigia 60: 153-155.

Denchev C.M. 1997. Additional finds of Microbotryum violaceoverrucosum (Ustilaginales). Bocconea 5: 849-852.

Denchev T.T. \& Denchev C.M. 2016. Ustanciosporium tropicoafricanum (Anthracoideaceae), a new smut fungus on Rhynchospora angolensis (Cyperaceae) from Zambia. Nova Hedwigia 102: 367-371.

Denchev T.T. \& Denchev C.M. 2017. A noteworthy range extension for Haradaea moenchiae-manticae, a rarely reported smut fungus. Mycobiota 7: 7-12.

Denchev T.T. \& Denchev C.M. 2019. Contributions to the smut fungi of Africa. 5. First record of Thecaphora thlaspeos. Mycobiota 9: 1-6.

Denchev T.T., Knudsen H. \& Denchev C.M. 2020a. The smut fungi of Greenland. MycoKeys 64: 1-164.

Denchev T.T., Scheuer C., Vitek E. \& Denchev C.M. 2020b. Bauerago vuyckii (Microbotryaceae) and Moreaua kochiana (Anthracoideaceae) new records from Austria. Mycobiota 10: 13-19.

Desmazières J.B.H.J. 1851. Plantes Cryptogames du Nord de la France ed. 1: no. 2126. In Desmazières J.B.H.J. 1825-1851. Plantes Cryptogames du Nord de la France ed. 1, fasc. 1-44, nos. 1-2200.

Durrieu G. 1966. Etude écologique de quelques groupes de champignons parasites des plantes spontanées dans les Pyrénées. Bulletin de la Société d'Histoire Naturelle de Toulouse 102: 7-277.

Elven R., Murray D.F., Razzhivin V.Y. \& Yurtsev B.A. (eds.) 2020 Annotated checklist of the Panarctic Flora (PAF). Vascular plants. Natural History Museum, University of Oslo. Website: http://panarcticflora.org/ [accessed: 12 Nov. 2020]

Ernst W.H.O. 2013. Moreaua kochiana, a new smut species for the Netherlands. Coolia 56: 129-130.

Fischer von Waldheim A.A. 1879. Über die von G. Ehrenberg in Aegypten und Nubien gesamelten Brandpilze. Hedwigia 18: 100.

Gäumann E. 1932. Ueber eine neue Ustilaginee. Bericht der Schweizerischen Botanischen Gesellschaft 41: 179.

Gonzáles Fragoso R. 1914. Nueva contribución a la flora micológica del Guadarrama. Teleomicetos y deuteromicetos (Adiciones). Trabajos del Museo Nacional de Ciencias Naturales, Serie Botánica 7: 1-80.

Gonzáles Fragoso R. 1917. Algunos micromicetos más de los alrededores de Melilla (Marruecos), recolectados por el Profesor D.A. Caballero. Boletín de la Real Sociedad Española de Historia Natural 17: 78-83.

Gonzáles Fragoso R. 1919. Anotaciones micológicas. Memorias de la Real Sociedad Española de Historia Natural 11: 77-123.

Gonzáles Fragoso R. 1923. Nueva serie de hongos del Herbario del Museo de Ciencias Naturales de Barcelona. Butlletí de la Institució Catalana d'Història Natural 23: 116-123.
González Fragoso R. 1924a. Ustilaginales de la flora española existentes en el Herbario del Museo Nacional de Ciencias Naturales de Madrid. Boletín de la Real Sociedad Española de Historia Natural 24: 116-127.

Gonzáles Fragoso R. 1924b. Datos para el conocimiento de la Micoflora Ibérica. Boletín de la Real Sociedad Española de Historia Natural 24: 440-452.

Gonzáles Fragoso R. 1926. Hongos de España (3. ${ }^{a}$ Serie). Brotéria, Série Botânica 22: 97-106.

Gouy M., Guindon S. \& Gascuel O. 2010. SeaView version 4: A multiplatform graphical user interface for sequence alignment and phylogenetic tree building. Molecular Biology and Evolution 27: 221-224.

Govaerts R. 2020. World checklist of Cyperaceae. Facilitated by the Royal Botanic Gardens, Kew. Website: https://wcsp.science.kew.org/ qsearch.do [accessed 7 Nov. 2020].

Guyot L., Malençon G. \& Massenot M. 1955. Contribution à l'étude des Ustilaginales parasites du Bassin méditerranéen occidental. (Afrique $\mathrm{du}$ Nord et Péninsule ibérique). Revue de Pathologie Végétale et d'Entomologie Agricole de France 34(4): 181-216.

Guyot L., Malençon G. \& Massenot M. 1958. Deuxième contribution à l'étude des Ustilaginales parasites du Bassin méditerranéen occidental. (Afrique du Nord et Péninsule ibérique). Revue de Pathologie Végétale et d'Entomologie Agricole de France 37(2): 187-196.

Guyot L., Malençon G. \& Massenot M. 1960. Troisième contribution à l'étude des Ustilaginales parasites du Bassin Méditerranéen Occidental (Afrique du Nord et Péninsule ibérique). Revue de Pathologie Végétale et d'Entomologie Agricole de France 39: 165-172.

Guyot L., Malençon G. \& Massenot M. 1969. Quatrième contribution à l'étude des Ustilaginales parasites du Bassin Méditerranéen Occidental (Afrique du Nord, Espagne, Italie). Revue de Mycologie, Paris 34: 192-219.

Helgi Hallgrímsson \& Guðríður Gyða Eyjólfsdóttir. 2004. Checklist of Icelandic fungi I. Microfungi. Fjölrit Náttúrufrææðistofnunar 45: 1-189. (In Icelandic)

Isabel M., Quintanar A. \& Medina L. 2018. Revisión taxonómica del género Briza (Poaceae) en la Península Ibérica e Islas Baleares. Collectanea Botanica 37: e004.

Jones B.M.G. \& Akeroyd J.K. 1993. Arabis L. In Tutin T.G. \& al. (eds.), Flora Europaea, ed. 2: 352-356. Cambridge University Press, Cambridge.

Jørstad I. 1962. Investigations on the Uredinales and other parasitic fungi in Mallorca and Menorca. Skrifter utgitt av det Norske VidenskapsAkademi i Oslo, Matematisk-Naturvidenskapelig Klasse 2: 1-73.

Jørstad I. 1963. Ustilaginales of Norway (exclusive of Cintractia on Carex). Nytt Magasin for Botanikk 10: 85-130.

Katoh K. \& Standley D.M. 2013. MAFFT multiple sequence alignment software version 7: improvements in performance and usability. Molecular Biology and Evolution 30: 772-780.

Katoh K., Misawa K., Kuma K. \& Miyata,T. 2002. MAFFT: a novel method for rapid multiple sequence alignment based on fast Fourier transform. Nucleic Acids Research 30: 3059-3066.

Kemler M., Denchev T.T., Denchev C.M., Begerow D., Piątek M. \& Lutz M. 2020. Host preference and sorus location correlate with parasite phylogeny in the smut fungal genus Microbotryum (Basidiomycota, Microbotryales). Mycological Progress 19: 481-493.

Kemler M., Martín M.P., Telleria T., Schäfer A.M., Yurkov A. \& Begerow D. 2013. Contrasting phylogenetic patterns of anther smuts (Pucciniomycotina: Microbotryum) reflect phylogenetic patterns of their caryophyllaceous hosts. Organisms, Diversity and Evolution 13: 111-126. 
Kruse J., Kummer V. \& Thiel H. 2014. Noteworthy records of phytopathogenic micromycetes (2): Further smut fungi (Ustilaginomycotina) Zeitschrift für Mykologie 80: 227-255.

Kruse J., Piątek M., Lutz M. \& Thines M. 2018. Broad host range species in specialised pathogen groups should be treated with suspicion - a case study on Entyloma infecting Ranunculus. Persoonia 41: 175-201.

Kruse J., Thiel H., Klenke F. \& Kummer V. 2019. Bemerkenswerte Funde phytoparasitischer Kleinpilze (12). Zeitschrift für Mykologie 85: 315-342.

Lehtola V.B. 1942. Zur Kenntnis der Brandpilze auf Rhynchospora alba (L.) Vahl. Annales Botanici Societatis Zoologicae-Botanicae Fennicae "Vanamo" 17(3): 1-34

Lindeberg B. 1959. Ustilaginales of Sweden (exclusive of the Cintractias on Caricoideae). Symbolae Botanicae Upsalienses 16(2):1-175.

Liro J.I. 1924. Die Ustilagineen Finnlands 1. Annales Academiae Scientiarum Fennicae, Ser. A 17(1): 1-636.

Liro J.I. 1936. Über Schizonella melanogramma und Verwandte. In Liro J.I. (1935-1938). Die Ustilagineen Finnlands 2. Annales Academiae Scientiarum Fennicae, Ser. A 42(1): 300-309.

Liro J.I. 1938. Die Ustilagineen Finnlands 2. Annales Academiae Scientiarum Fennicae, Ser. A 42(1): 1-720.

Llorens i Villagrasa I. 1985. Aportación al conocimiento de los Uredinales, Ustilaginales y Fragmobasidiomicetos de España. I. Anales de Biología, Facultad de Biología, Universidad de Murcia 1: 35-45.

Losa España T.M. 1942. Aportación al estudio de la Flora Micològica española. Anales del Jardín Botánico de Madrid 2: 87-142.

Losa España T.M. 1944. Aportaciones a la flora micològica gallega. Anales del Jardín Botánico de Madrid 4: 195-240.

Losa España T.M. 1949. Aportación al estudio de la Micologia catalana. Collectanea Botanica 2(2): 205-225.

Losa España T.M. 1954. Aportaciones al estudio de la Flora Micològica Española. Anales del Instituto Botánico A. J. Cavanilles 12: 265-297.

Losa Quintana J.M. 1970. Contribución al estudio de los micromicetes españoles. Anales del Instituto Botánico A. J. Cavanilles 26: 5-14.

Lutz M., Piątek M., Kemler M., Chlebicki A. \& Oberwinkler F. 2008. Anther smuts of Caryophyllaceae: molecular analyses reveal further new species. Mycological Research 112: 1280-1296.

Maire R. 1917. Schedae ad Mycothecam Boreali-Africanam. Fasciculus 10. Bulletin de la Société d'Histoire Naturelle de l'Afrique du Nord 8: 74-83.

Maire R. 1933. Fungi Catalaunici. Contributions à l'étude de la Flore Mycologique de la Catalogne. Treballs de l'Institut Botànic de Barcelona 3(2): 1-120.

Maire R. 1943. Fungorum Nevadensium. Pugillus alter. Anales del Jardín Botánico de Madrid 3: 51-52.

McKenzie E.H.C. \& Vánky K. 2001. Smut fungi of New Zealand: An introduction, and list of recorded species. New Zealand Journal of Botany 39: $501-515$

Nannfeldt J.A. 1977. The species of Anthracoidea (Ustilaginales) on Carex subgen. Vignea with special regard to the Nordic species. Botaniska Notiser 130: 351-375.

Piątek M., Lutz M. \& Kemler M. 2013. Microbotryum silenes-saxifragae sp. nov. sporulating in the anthers of Silene saxifraga in southern European mountains. IMA Fungus 4: 29-40.
Piątek M., Piatek J. \& Mossebo D.C. 2012. Recently discovered collections extend the geographical range of the smut fungus Sphacelotheca polygoniserrulati to Cameroon and Zambia. Polish Botanical Journal 57: 285-293.

Piepenbring M. 2000. The species of Cintractia s. 1. (Ustilaginales, Basidiomycota). Nova Hedwigia 70: 289-372.

RambautA. 2016. FigTree v1.4.3. Institute of Evolutionary Biology, University of Edinburgh, Edinburgh. Website: http://ree.bio.ed.ac.uk/software/figtree/ [accessed: 7 Dec. 2020].

Rayner RW. 1970. A Mycological Colour Chart. CMI, Surrey \& British Mycological Society, Kew.

Stamatakis A. 2006. RAxML-VI-HPC: maximum likelihood-based phylogenetic analyses with thousands of taxa and mixed models. Bioinformatics 22: 2688-2690.

Sydow H. 1924. Notizen über Ustilagineen. Annales Mycologici 22: 277-291.

Sydow H. 1937. Novae fungorum species. 25. Annales Mycologici 35: 244 286.

Talavera S. 1993. Arabis L. In Castroviejo S. \& al. (eds.), Flora iberica 4: 135-163. Editorial CSIC, Real Jardín Botánico, Madrid.

Thirumalachar M.J. \& Neergaard P. 1978. Studies on the genus Tolyposporium. Tolyposporidium gen. nov. Friesia 11['1977’]: 177-192.

Unamuno L.M. 1928. Datos para el estudio de la flora micológica de los alrededores de Santa Maria de la Vid (Burgos). Boletín de la Real Sociedad Española de Historia Natural 28: 195-202.

Unamuno L.M. 1930a. Nueva aportación a la micologia española. Boletín de la Real Sociedad Española de Historia Natural 30: 287-301.

Unamuno L.M. 1930b. Hongos microscópicos de los alrededores de Caudete (Albacete). Boletín de la Real Sociedad Española de Historia Natural 30: 379-390.

Unamuno L.M. 1930c. Datos para el conocimiento de la micoflora española. Boletín de la Real Sociedad Española de Historia Natural 30: 419-434.

Unamuno L.M. 1931. Algunas especies de micromicetos de la región meridional de España. Boletín de la Real Sociedad Española de Historia Natural 31: 331-340.

Unamuno L.M. 1934a. Notas micológicas, 7. Algunos datos interesantes para la flora micológica española. Boletín de la Real Sociedad Española de Historia Natural 34: 133-146.

Unamuno L.M. 1934b. Notas micológicas, 8. Boletín de la Real Sociedad Española de Historia Natural 34: 249-259.

Unamuno L.M. 1942. Contribución al estudio de los hongos microscópicos de la provincia de Cuenca. Anales del Jardin Botánico de Madrid 2: 7-86.

Vaidya G., Lohman D.J. \& Meier R. 2011. SequenceMatrix: concatenation software for the fast assembly of multi-gene datasets with character set and codon information. Cladistics 27: 171-180.

Vánky K. \& Oberwinkler F. 1994. Ustilaginales on Polygonaceae - a taxonomic revision. Nova Hedwigia Beiheft 107: 1-96.

Vánky K. \& Shivas R.G. 2008. Fungi of Australia: the smut fungi. In Fungi of Australia Series. Australian Biological Resources Study, Canberra \& CSIRO Publishing, Melbourne.

Vánky K. 1988. Taxonomical studies on Ustilaginales. 3. Mycotaxon 33: 365-374.

Vánky K. 1994. European Smut Fungi. Gustav Fischer Verlag, Stuttgart, Jena, New York 
Vánky K. 1998. Ustilaginales exsiccata. Fasc. 41-42 (no. 1001-1050). Publications from the Herbarium Ustilaginales Vánky 12: 1-17.

Vánky K. 2000. New taxa of Ustilaginomycetes. Mycotaxon 74: 343-356. Vánky K. 2003. Taxonomical studies on Ustilaginales. 23. Mycotaxon 85: 1-65

Vánky K. 2004. Taxonomic studies on Ustilaginomycetes - 24. Mycotaxon 89: 55-118.

Vánky K. 2005. European smut fungi (Ustilaginomycetes p.p. and Microbotryales) according to recent nomenclature. Mycologia Balcanica 2: 169-177.
Vánky K. 2011['2012’]. Smut fungi of the world. APS Press, St. Paul, Minnesota, USA.

Vánky K., Vánky C. \& Denchev C.M. 2011. Smut fungi in Africa - a checklist. Mycologia Balcanica 8: 1-77.

Zundel G.L. 1938. The Ustilaginales of South Africa. Bothalia 3: 283-330.

Zundel G.L. 1944. Notes on the Ustilaginales of the world. 4. Mycologia 36: $400-412$. 